CZASOPISMO INŻYNIERII LĄDOWEJ, ŚRODOWISKA I ARCHITEKTURY JOURNAL OF CIVIL ENGINEERING, ENVIRONMENT AND ARCHITECTURE

JCEEA, t. XXXIV, z. 64 (3/I/17), lipiec-wrzesień 2017, s. 123-139, DOI: 10.7862/rb.2017.109

\author{
Agnieszka MACHOWSKA ${ }^{1}$ \\ Paweł KOSIŃSKI ${ }^{2}$
}

\title{
PROJEKTOWANIE ZAMKNIĘĆ HYDROTECHNICZNYCH WEDEUG EUROKODÓW NA PRZYKŁADZIE KLAPY SOCZEWKOWEJ
}

\begin{abstract}
W artykule przedstawiono wyniki analizy oddziaływań działających na zamknięcie hydrotechniczne w postaci klapy soczewkowej zainstalowanej na segmencie podnoszonym oraz nośności klapy pracującej jako ustrój cienkościenny o profilu zamkniętym. Obliczenia wykonano według obowiązujących norm - Eurokodów (PN-EN 1990, PN-EN 1993-1-1, PN-EN 1993-1-3, PN-EN 1993-1-7 oraz PN-EN 1993-4), oraz wycofanych norm (PN-B-03200 i PN-B-03203). Przeanalizowano wartości efektów oddziaływań dla sześciu położeń klapy. Analiza wyników wskazuje, że wartości oddziaływań wyznaczone według Eurokodów są wyższe dla warunków eksploatacyjnych i znacząco niższe dla warunków wyjątkowych pracy zamknięcia w porównaniu do oddziaływań wyznaczonych zgodnie z zasadami przedstawionymi w wycofanej normie. Wskazuje to na konieczność wydania opracowania do norm obowiązujących, które regulowałoby wartości współczynników częściowych stosowanych w projektowaniu zamknięć hydrotechnicznych, gdyż te podane w Eurokodach nie odzwierciedlają charakteru obciążenia działającego na budowle wodne. W dalszej części artykułu przedstawiono wyniki obliczeń statyczno - wytrzymałościowych dla najbardziej niekorzystnego przypadku obciążenia. Analiza wyników weryfikacji stanu granicznego nośności klapy soczewkowej wskazuje, że można bezpiecznie zaprojektować stalowe zamknięcie wodne bazując na zapisach zawartych w normach zharmonizowanych. Jest to proces pracochłonny, a największą trudność stanowi ustalenie obliczeniowych wartości efektów oddziaływań. Ze względu na specyfikę konstrukcji stalowych zamknięć wodnych i warunków ich pracy niezbędne jest opracowanie przepisów regulujących zasady jakie należy zachować podczas ich projektowania.
\end{abstract}

Słowa kluczowe: zamknięcie hydrotechniczne, klapa soczewkowa, oddziaływania, parcie wody

\footnotetext{
${ }^{1}$ Autor do korespondencji / corresponding author: Agnieszka Machowska, Politechnika Warszawska Wydział Instalacji Budowlanych Hydrotechniki i Inżynierii Środowiska, ul. Nowowiejska 20, 00-653 Warszawa, 2223453 33, agnieszka.machowska@pw.edu.pl

${ }^{2}$ Paweł Kosiński, Politechnika Warszawska Wydział Instalacji Budowlanych Hydrotechniki i Inżynierii Środowiska, ul. Nowowiejska 20, 00-653 Warszawa
} 


\section{Wprowadzenie}

Projektowanie konstrukcji jest regulowane przepisami zawartymi w normach europejskich wdrożonych w Polsce od 2010 r. - tzw. Eurokodach. Pakiet norm zharmonizowanych zawiera szereg części służących projektantom do projektowania różnego rodzaju konstrukcji. Projektując obiekt zgodnie z obowiązującymi zasadami należy korzystać ze zbioru norm dotyczących reguł ogólnych, wielkości obciążeń oraz zasad sprawdzania nośności poszczególnych elementów projektowanej konstrukcji. Zbiór norm do projektowania konstrukcji stalowych liczy kilkanaście części, jednak brak jest w nich regulacji dotyczących projektowania stalowych zamknięć hydrotechnicznych. W obecnym stanie projektanci mogą korzystać z dostępnych części Eurokodów dotyczących projektowania budynków lub zbiorników na ciecze albo z norm wycofanych.

\section{Analiza oddziaływań przykładowej konstrukcji hydrotechnicznej}

W artykule przedstawiono obliczenia wielkości efektów oddziaływań na zamknięcie stalowe w postaci klapy soczewkowej (zamknięcie klasy III wg [8]), zainstalowanej na segmencie, o następujących parametrach (rys. 1.):

- długość zamknięcia: 14,0 m,

- wysokość piętrzenia klapy: 1,5 m,

- promień krzywizny klapy: 3,5 m,

- stal S355.

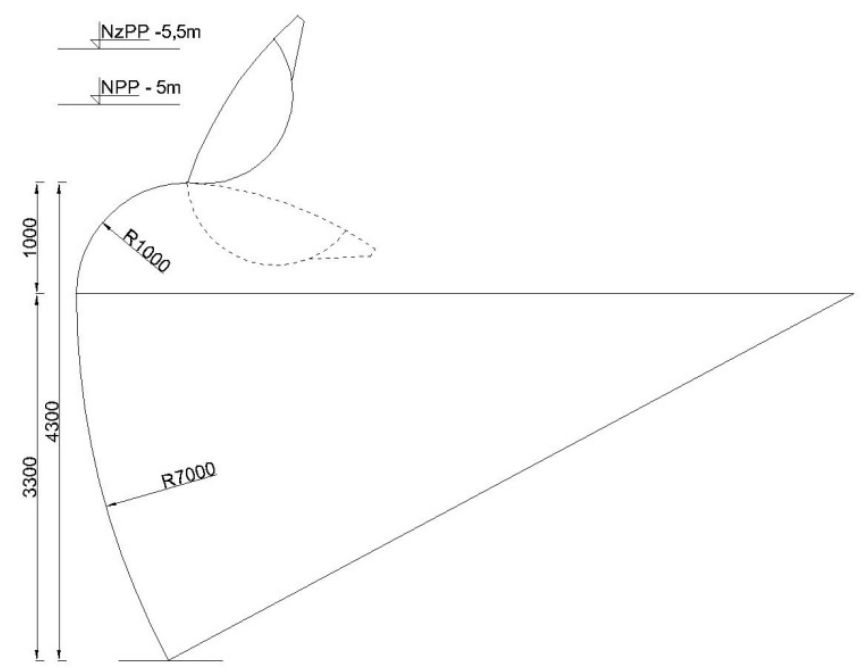

Rys. 1. Schemat zamknięcia w postaci segmentu z klapą

Fig. 1. Scheme of segment and flap gate 
Wyznaczając efekty oddziaływań od parcia wody na zamknięcie w trwałej sytuacji obliczeniowej (warunki eksploatacyjne) zgodnie z PN-EN 1990 [3] przyjmuje się wzory 6.10a i 6.10b:

$$
\begin{aligned}
& \sum_{j \geq 1} \gamma_{G, j} G_{k, j} "+" \gamma_{Q, 1} \psi_{0,1} Q_{k, 1} "+" \sum_{i>1} \gamma_{Q, i} \psi_{0, i} Q_{k, i} \\
& \sum_{j \geq 1} \xi \gamma_{G, j} G_{k, j} "+" \gamma_{Q, 1} Q_{k, 1} "+" \sum_{i>1} \gamma_{Q, i} \psi_{0, i} Q_{k, i}
\end{aligned}
$$

w których:

$G_{k, j}$ - wartość charakterystyczna oddziaływania stałego $j$,

$Q_{k, 1}$ - wartość charakterystyczna oddziaływania zmiennego wiodącego,

$Q_{k, i}$ - wartość charakterystyczna oddziaływania zmiennego towarzyszącego $i$,

$\gamma_{G, j}$ - współczynnik częściowy dla $j$-tego oddziaływania stałego,

$\gamma_{Q, 1}$ - współczynnik częściowy dla wiodącego oddziaływania zmiennego,

$\gamma_{Q, i}$ - współczynnik częściowy dla $i$-tego oddziaływania zmiennego,

$\psi_{0,1}$ - współczynnik dla wartości kombinacyjnej wiodącego oddziaływania zmiennego,

$\psi_{0, i}$ - współczynnik dla wartości kombinacyjnej $i$-tego oddziaływania zmiennego, $\xi$ - współczynnik redukcyjny dla oddziaływań stałych.

W przypadku wyjątkowej sytuacji obliczeniowej, którą należy przeanalizować projektując zamknięcie wodne, przyjmuje się wartości obliczeniowych efektów oddziaływań ze wzoru $6.11 \mathrm{~b}$ z normy [3]:

$$
\sum_{j \geq 1} G_{k, j} "+" A_{d} "+"\left(\psi_{1,1} l u b \psi_{2,1}\right) Q_{k, 1} "+\text { " } \sum_{i>1} \psi_{2, i} Q_{k, i}
$$

w którym:

$A_{d}$ - wartość obliczeniowa oddziaływania wyjątkowego,

$\psi_{1,1}$ - współczynnik dla wartości częstej oddziaływania wiodącego zmiennego,

$\psi_{2,1}$ - współczynnik dla wartości prawie stałej dla oddziaływania wiodącego zmiennego,

$\psi_{2, i}$ - współczynnik dla wartości prawie stałej dla $i$-tego oddziaływania zmiennego.

W przypadku wycofanej normy dotyczącej projektowania stalowych zamknięć hydrotechnicznych [2] oddziaływania na zamknięcie należy wyznaczać dla:

- kombinacji podstawowej wg wzoru:

$$
\sum_{j \geq 1} \gamma_{f} \cdot G_{k}+\sum_{i>1} \gamma_{f} Q_{k, d ł}+\max \left(\gamma_{f} \cdot Q_{k, k}\right)
$$

w którym:

$Q_{k, d ł}$ - obciążenie zmienne długotrwałe,

$Q_{k, k}$ - obciążenie zmienne krótkotrwałe, 
- kombinacji rozszerzonej wg wzoru:

$$
\sum_{j \geq 1} \gamma_{f} \cdot G_{k}+\sum_{i>1} \gamma_{f} Q_{k, d\}}+\sum_{i>1} \gamma_{f} \cdot Q_{k, k} \cdot \psi_{d}
$$

w którym:

$\psi_{d}$ - współczynnik jednoczesności obciążeń,

- kombinacji wyjątkowej wg wzoru:

$$
\sum_{j \geq 1} \gamma_{f} \cdot G_{k}+\sum_{i>1} \gamma_{f} Q_{k, d ł}+\sum_{i>1} \gamma_{f} \cdot Q_{k, k} \cdot \psi_{d}+A_{d} \cdot \gamma_{f}
$$

Na rysunku 2. przedstawiono osiem możliwych położeń klapy, począwszy od najwyższego - położenie nr 1 - po całkowite jej opuszczenie - położenie nr 8. Zrezygnowano z wykonania analizy dla wariantu 7 i 8 ze względu na fakt, że grubość warstwy wody przelewającej się przez klapę, a co za tym idzie także oddziaływania są mniejsze niż w wariancie 6 .

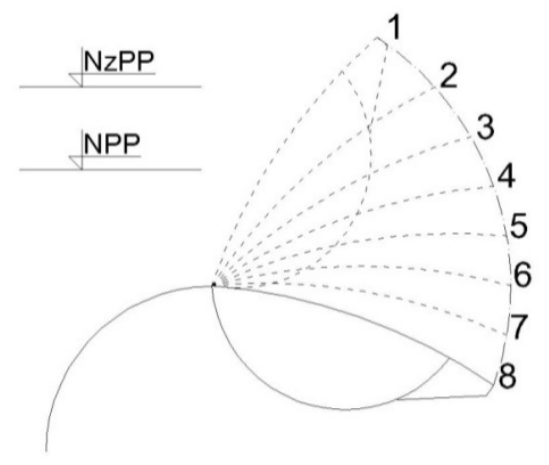

Rys. 2. Analizowane warianty położenia klapy

Fig. 2. Analyzed positions of flap gate

Na rysunku 3. przedstawiono schematycznie oddziaływania w wyjątkowej sytuacji obliczeniowej działające na klapę w położeniu $\mathrm{nr} 2$. W analizie uwzględniono parcie hydrostatyczne wody, nadpiętrzenie hydrostatyczne wody oraz obciążenie wyjątkowe od parcia wody. Podano wymiary poszczególnych wykresów parcia oraz położenie ich środków ciężkości.

Ze względu na brak w Eurokodach wytycznych dotyczących projektowania stalowych zamknięć hydrotechnicznych, wykonując obliczenia oddziaływań zastosowano $\mathrm{w}$ wariancie pierwszym wartości współczynników częściowych podane w części normy dot. reguł projektowania budynków [3] oraz, w wariancie drugim, dot. projektowania zbiorników na ciecze [7], jako konstrukcji pokrewnych. $\mathrm{W}$ celu porównania wykonano także obliczenia zgodnie $\mathrm{z}$ wycofaną normą [2]. Wartości współczynników przedstawiono w tabeli 1. 

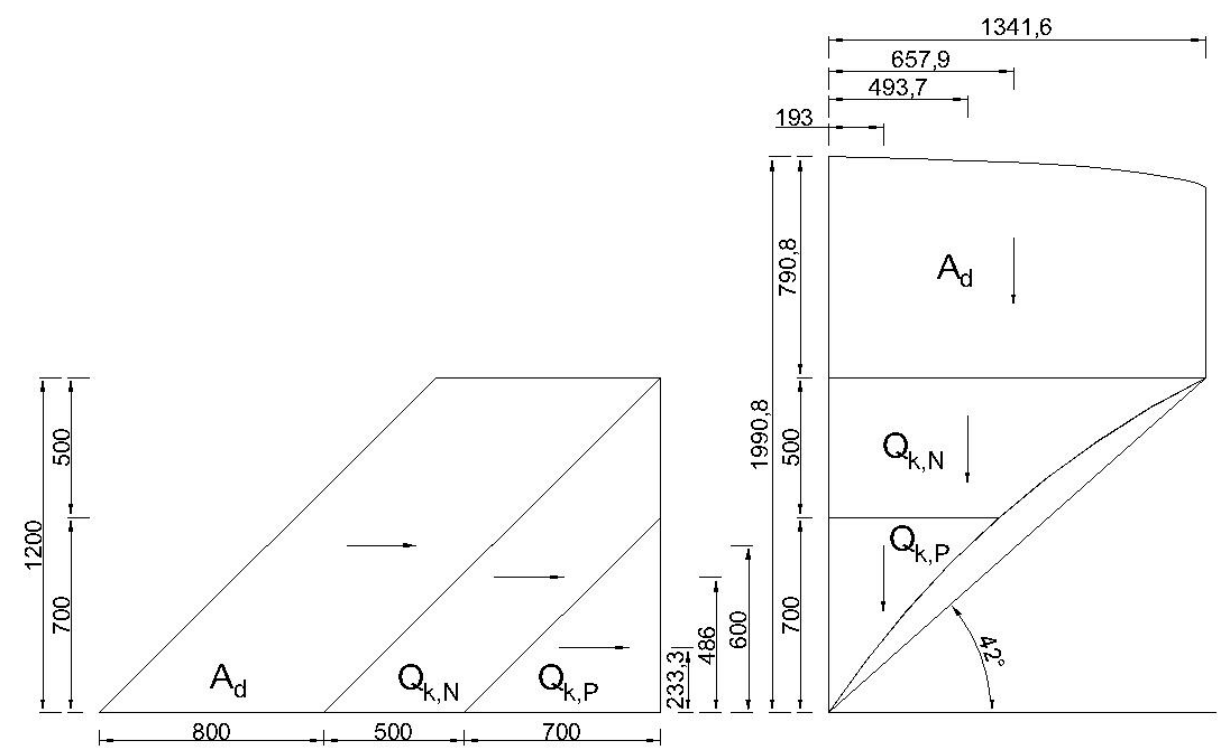

Rys. 3. Przykład podziału oddziaływań na klapę w położeniu nr 2 w wyjątkowej sytuacji obliczeniowej; $Q_{k, P}$ - parcie hydrostatyczne wody, $Q_{k, N}$ - nadpiętrzenie hydrostatyczne wody, $A_{d}$ - obciążenie wyjątkowe od parcia wody

Fig. 3. Example of actions in position no. 2 of flap gate in accidental design situation; $Q_{k, P}-$ hydrostatic water pressure, $Q_{k, N}$ - hydrostatic pressure at unusual water level, $A_{d}$ - pressure at accidental water level

Tabela 1. Zestawienie wartości współczynników częściowych $\gamma_{F}$ oraz $\psi_{i}$

Table 1. Values of partial factors $\gamma_{F}$ and $\psi_{i}$

\begin{tabular}{|c|c|c|c|}
\hline Współczynnik & PN-EN 1990 & PN-EN 1993-4-2 & PN-B-03203 \\
\hline$\gamma_{G}$ & 1,35 & 1,35 & \multirow{2}{*}{$\begin{array}{l}1,20 \text { - ciężar konstrukcji } \\
1,35 \text { - parcie zasadnicze hydrostatyczne } \\
1,35 \text { - nadpiętrzenie hydrostatyczne } \\
1,35 \text { - nadpiętrzenie wyjątkowe hydrosta- } \\
\quad \text { tyczne } \\
\text { 1,30 - parcie lodu }\end{array}$} \\
\hline$\gamma_{Q(1, i)}$ & 1,50 & 1,20 & \\
\hline$\xi$ & 0,85 & 0,90 & - \\
\hline$\psi_{0,1}$ & - & 1,00 & - \\
\hline$\psi_{0, i}$ & - & 1,00 & - \\
\hline$\psi_{1,1}$ & - & 1,00 & - \\
\hline$\psi_{2,1}$ & - & 1,00 & - \\
\hline$\psi_{2, i}$ & - & 1,00 & - \\
\hline$\psi_{d}$ & - & - & $\begin{array}{l}0,90 \text { - kombinacja rozszerzona } \\
0,80 \text { - kombinacja wyjątkowa }\end{array}$ \\
\hline
\end{tabular}


Można zauważyć, że w normach [3] i [7] dobiera się współczynniki częściowe dla danego rodzaju oddziaływania: stałe lub zmienne. W przypadku normy wycofanej [2] zróżnicowano współczynniki dotyczące obciążenia zmiennego w zależności od jego typu (np. nadpiętrzenie hydrostatyczne wody czy parcie lodu). W normie [2] nie ma odpowiednika współczynnika redukcyjnego dla oddziaływań stałych ( $\xi$ ) co wynika $\mathrm{z}$ faktu, że oddziaływanie to w postaci ciężaru zamknięcia jest niewielkie w porównaniu do oddziaływań zmiennych, takich jak hydrostatyczne parcie zasadnicze czy nadpiętrzenie wody.

Doboru wartości współczynnika $\psi_{0,1}$ i $\psi_{0, i}$ dokonano w sposób przybliżony na podstawie ogólnych wytycznych zawartych w [3] i [7] jak dla towarzyszącego oddziaływania zmiennego przy napełnianiu zbiornika na ciecze lub przy pełnym zbiorniku. Wartości współczynników $\psi_{1,1}, \psi_{2,1}, \psi_{2, i}$ wykorzystanych do wyznaczenia kombinacji oddziaływań wyjątkowych w przypadku zbiorników na ciecze, zgodnie z [7], przyjęto równe 1,0.

Wyniki obliczeń wartości poszczególnych oddziaływań eksploatacyjnych i wyjątkowych zgodnie z normami [3], [7] i [2] przedstawiono na rys. 2-3.

Analizując wykresy oddziaływań poziomych eksploatacyjnych wyznaczonych wg wytycznych w [3] - wariant 1, oraz w [7] - wariant 2 można zauważyć, że otrzymane wartości różnią się od siebie o ok. $20 \%$, co jest wynikiem zastosowania różnych wartości współczynników częściowych dot. oddziaływań zmiennych (tab. 1.). Porównując oddziaływania eksploatacyjne wyznaczone zgodnie z Eurokodami do oddziaływań obliczonych wg wycofanej polskiej normy [2] obserwuje się, że wartości wyznaczone dla kombinacji podstawowej są o ok. $15 \%$ niższe niż wyznaczone wg wzoru $6.10 \mathrm{a}$ i $6.10 \mathrm{~b}$ z [3], natomiast w sto-

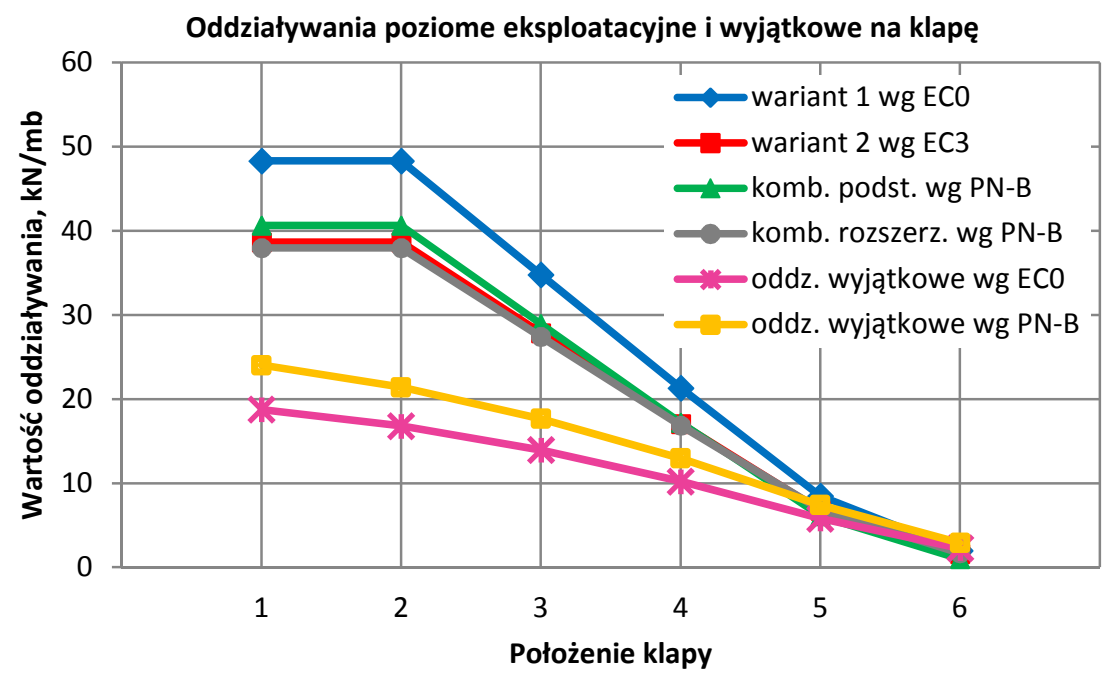

Rys. 4. Wartości oddziaływań poziomych na klapę wyznaczone zgodnie z [3], [7] oraz [2]

Fig. 4. Values of horizontal actions on flap gate calculated acc. to [3], [7] and [2] 


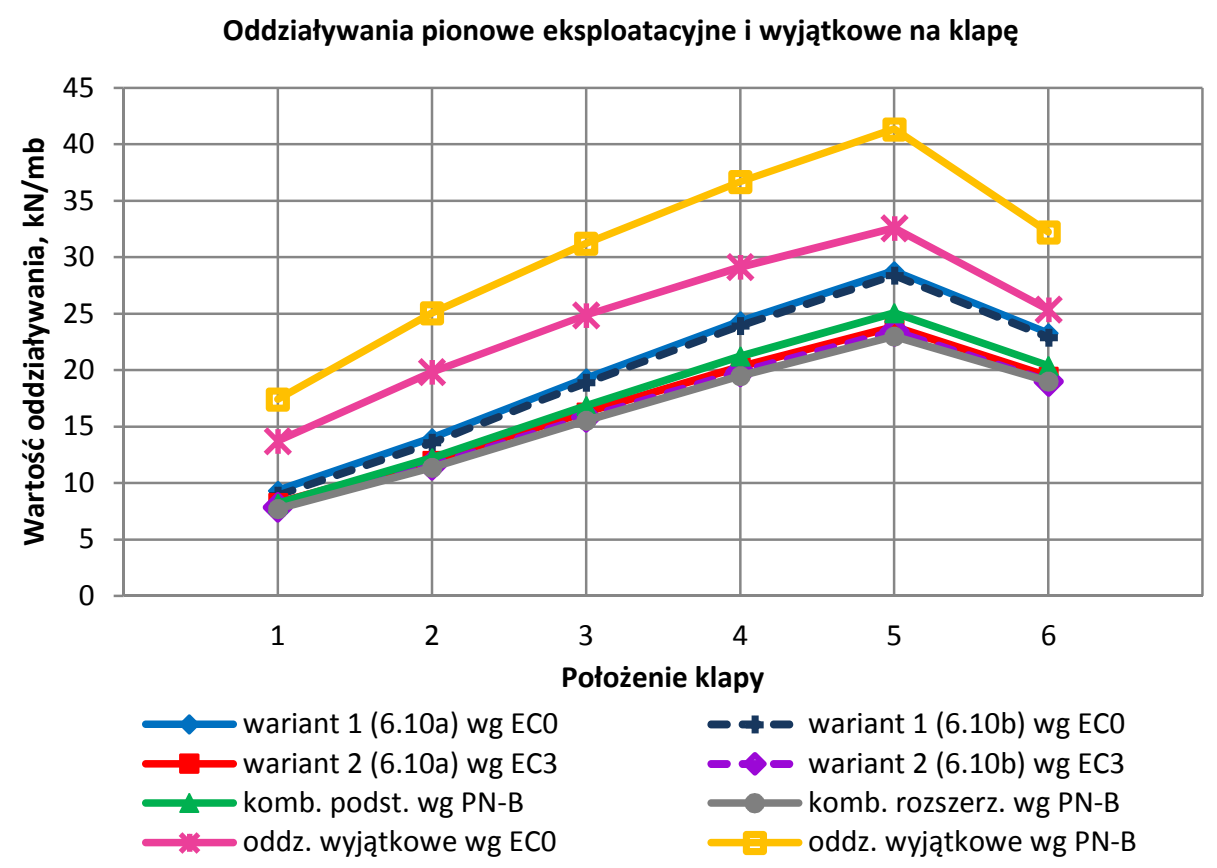

Rys. 5. Wartości oddziaływań pionowych na klapę wyznaczone zgodnie z [3], [7] oraz [2]

Fig. 5. Values of vertical actions on flap gate calculated acc. to [3], [7] and [2]

sunku do wartości wyznaczonych wg [7] są o ok. 5\% wyższe. W przypadku kombinacji rozszerzonej wartości oddziaływań są niższe w stosunku do pozostałych. Wynika to z braku regulacji dotyczących wartości współczynników częściowych oddziaływań oraz współczynników wartości kombinacyjnej dla budowli i urządzeń hydrotechnicznych. W obecnej sytuacji słuszne wydaje się stosowanie współczynników, które można znaleźć w normie dot. projektowania zbiorników na ciecze [7].

W przypadku oddziaływań poziomych wyjątkowych uzyskano inne wyniki: wartości obliczone zgodnie z Eurokodami są o ok. $22 \%$ niższe od wartości wyznaczonych wg normy polskiej [2]. Oznacza to, że współczynniki przyjęte do wyznaczenia oddziaływań wyjątkowych w przypadku zbiorników na ciecze niestety nie odwzorowują charakteru przyjętych obciążeń przy projektowaniu zamknięcia hydrotechnicznego. Przyjęcie wartości podanych w normie [7] skutkuje niższymi wartościami obciążeń innych niż wyjątkowe, które przy założonych schematach obliczeniowych nie ma racji bytu bez obciążeń zmiennych od piętrzenia zasadniczego i napiętrzenia wody.

Analizując wykres obrazujący oddziaływania pionowe (rys. 3.) eksploatacyjne na klapę, które w przypadku obliczeń zgodnie z [3] wyznaczono dla obu kombinacji 6.10a i 6.10b można zauważyć, że w obu przypadkach otrzymuje się 
wartości większe o ok. 12\% niż w przypadku kombinacji podstawowej wg [2]. Oddziaływania obliczone z wykorzystaniem współczynników podanych w normie dot. projektowania zbiorników na ciecze [7] są o ok. 5\% mniejsze w porównaniu do wartości uzyskanych w kombinacji podstawowej wyznaczonej zgodnie z normą wycofaną. W przypadku oddziaływań wyjątkowych można zauważyć, że wartości uzyskane z obliczeń zgodnie z normą [3] są o ok. $21 \%$ niższe od wartości wyznaczonych wg normy polskiej, co potwierdza wyżej postawiony wniosek o konieczności opracowania wartości współczynników częściowych, dotyczących oddziaływań na budowle i urządzenia hydrotechniczne.

\section{Projektowanie klapy soczewkowej}

W artykule przestawiono obliczenia statyczno-wytrzymałościowe klapy soczewkowej, którą projektuje się jako pręt cienkościenny o przekroju zamkniętym (rys. 7.). Ruszt piętrzący klapy składa się z belek poziomych zainstalowanych między przeponami, stanowiących stężenie podłużne klapy. Przepony poprzeczne zapewniają nieodkształcalność konturu poprzecznego klapy, a co za tym idzie właściwą pracę ustroju cienkościennego. Rozstaw przepon przyjęto jako $1 \mathrm{~m}$ (w punktach podparcia ustroju).

Obliczenia wytrzymałościowe wykonano równolegle wg wycofanych norm polskich [1] i [2] oraz obowiązującego pakietu norm zharmonizowanych (Eurokodów). Przyjęty przekrój poprzeczny klapy soczewkowej przedstawiono na rys. 6.

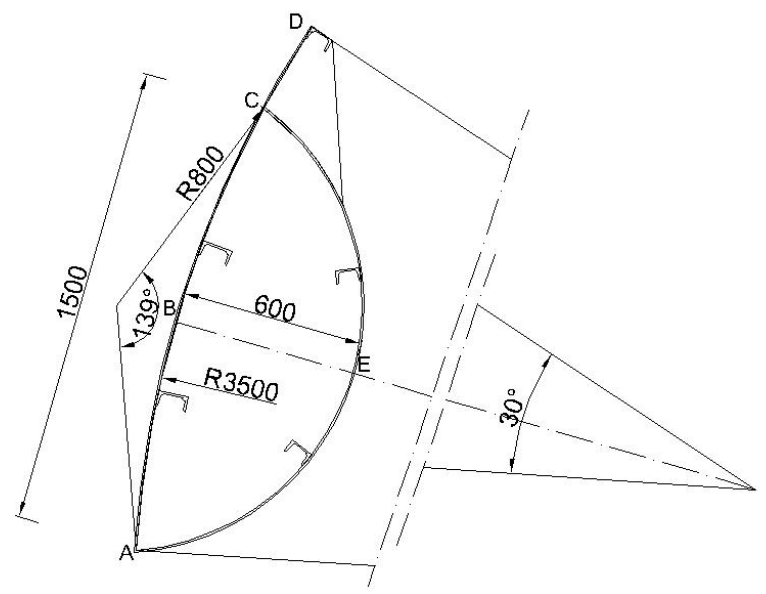

Rys. 6. Wymiary charakterystyczne klapy soczewkowej

Fig. 6. Characteristic dimensions of flap gate 


\subsection{Blacha opierzająca}

Grubość blachy opierzającej wyznaczono na podstawie [2] ze wzoru:

$$
\sigma_{x / y}= \pm K_{x / y} \frac{p \cdot b^{2}}{t^{2}}
$$

$K$ - współczynnik zależny od sposobu podparcia blachy i proporcji jej wymiarów,

$p$ - ciśnienie wody na środku płyty,

$b$ - szerokość płyty,

$t$ - grubość płyty.

Obliczono wytrzymałość w złożonym stanie naprężenia wg wzoru Hubera:

$$
\sigma_{z}=\sqrt{\sigma_{x}^{2}+\sigma_{y}^{2}-\sigma_{x} \cdot \sigma_{y}} \leq f_{d}
$$

$\sigma_{x}, \sigma_{y}-$ składowe normalne naprężenia.

Zgodnie z normą PN-EN 1993-1-7 [6] grubość płyty wyznacza się w ten sam sposób, a naprężenia zastępcze należy odnieść do granicy plastyczności stali:

$$
\sigma_{e q, E d}=\sqrt{\sigma_{b x, E d}^{2}+\sigma_{b y, E d}^{2}-\sigma_{b x, E d} \cdot \sigma_{b y, E d}} \leq \frac{f_{y k}}{\gamma_{M 0}}
$$

$\sigma_{b x, E d}, \sigma_{b y, E d}$ - sumaryczne naprężenia normalne.

Przyjęto grubość blachy opierzającej równą $6 \mathrm{~mm}$. Obliczenia przeprowadzono przy założeniu, że każda płyta pracuje jako utwierdzona na wszystkich czterech krawędziach (spawana do przepon i belek poziomych). Naprężenia zastępcze w blasze przyjmują wartości:

a) wg normy [2]: $\sigma_{z}=50,22 \mathrm{MPa}$,

b) wg normy [6]: $\sigma_{e q, E d}=59,52 \mathrm{MPa}$.

Różnice w wartościach naprężeń zastępczych w blasze opierzającej obliczonych wg [2] i [6] wynikają z wykorzystania wyższych wartości oddziaływań wyznaczonych na podstawie normy [3].

W wycofanej normie PN-B-03203 [2] znajduje się przepis narzucający minimalną grubość blachy konstrukcji zamknięć głównych równą $6 \mathrm{~mm}$. Wymaganie to wynikało z konieczności zapewnienia możliwości manewrowania zamknięciem $\mathrm{w}$ płynącej wodzie $\mathrm{w}$ przewidzianym czasie. Takiego warunku nie ma w normach zharmonizowanych, stąd minimalną grubość blachy w przypadku projektowania klapy zgodnie z tymi normami, należy przyjąć jako tę, która zapewni nośność konstrukcji powłokowej w złożonym stanie naprężenia oraz trwałość ze względu na warunki korozyjne pracy zamknięcia. 


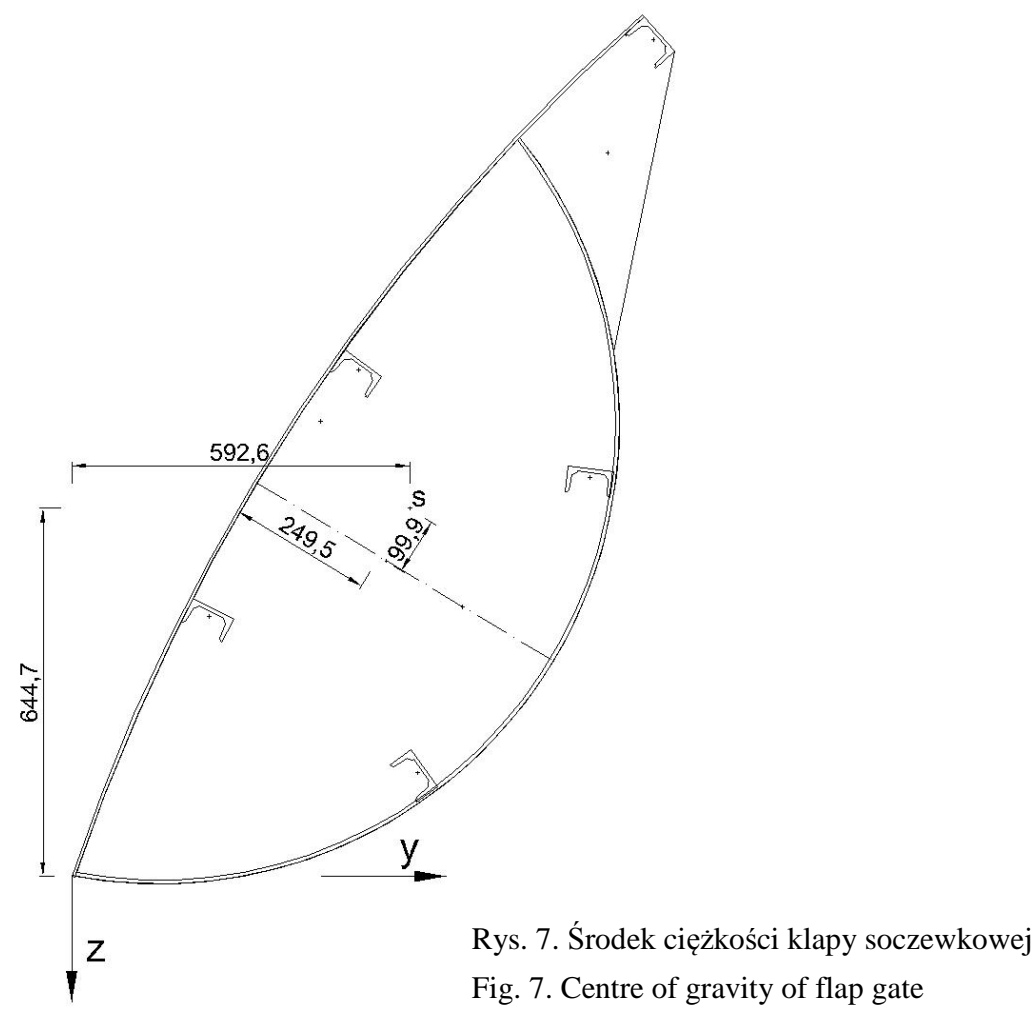

\subsection{Belki poziome}

Belki poziome stanowią stężenia podłużne klapy soczewkowej. Projektuje się je z profili walcowanych, jako elementy zginane. Belki poziome są na całej długości spawane do blachy opierzającej, stąd przy sprawdzaniu nośności belki fragment blachy wlicza się do współpracy. W celu wyznaczenia długości blachy współpracującej zgodnie z normą [2] uwzględnia się rodzaj działającego obciążenia oraz proporcje płyty:

$$
s_{1}=v_{1} \cdot 0,5 b
$$

$b$ - rozpiętość blachy między belkami,

$v_{1}$ - współczynnik dla obciążenia równomiernie rozłożonego (rys. B2 z [2]).

Wyznaczenie długości blachy współpracującej zgodnie z [4] wynika z ograniczeń przekroju klasy 3:

$$
\frac{\mathrm{c}}{t} \leq 14 \varepsilon
$$

$t$ - grubość blachy opierzającej. 
Stąd długość blachy współpracującej wynosi: $s_{1}=2 c+b_{f}$.

Długość blachy współpracującej ze zginanym przekrojem wynosi:

a) wg normy [2]: $s_{1}=38,5 \mathrm{~cm}$,

b) wg normy [4]: $s_{l}=17 \mathrm{~cm}$.

Belkę poziomą rusztu piętrzącego projektuje się jako zginaną zgodnie z [1] wg wzoru:

$$
\frac{M}{\varphi_{L} \cdot M_{R}} \leq 1
$$

uwzględniając w nośności elementu wytrzymałość obliczeniową stali, z której belka jest wykonana oraz miejscową niestateczność ścianki przekroju.

Sprawdzenie stateczności na zwichrzenie elementu zginanego zgodnie z [4] wykonuje się wg wzoru:

$$
\frac{M_{E d}}{M_{b, R d}} \leq 1
$$

uwzględniając w nośności elementu granicę plastyczności oraz współczynnik zwichrzenia.

W normie wycofanej [2] dot. projektowania zamknięć hydrotechnicznych podano zalecenia konstrukcyjne dot. minimalnych wymiarów elementów nośnych w zamknięciach głównych, którym należy zapewnić możliwość manewrowania w płynącej wodzie w przewidzianym czasie. Minimalna wielkość ceownika walcowanego to C80. Takich zaleceń nie ma w normach zharmonizowanych, stąd projektując belkę poziomą wybrano ceownik minimalny spełniający warunek stateczności: C50 (wytężenie 52\%). Ustalając wielkości oddziaływań na belki poziome zgodnie z [2] i [3] uwzględniono współczynniki częściowe dla danego rodzaju obciążenia oraz współczynnik konsekwencji zniszczenia podany w Rozporządzeniu Min. Środowiska [8]. Przedstawione w normie obowiązującej [3] współczynniki konsekwencji dotyczą jedynie budynków, których czas eksploatacji przewidziano na 50 lat.

\subsection{Przekrój cienkościenny o profilu zamkniętym}

W celu sprawdzenia stanu granicznego nośności klapy soczewkowej poddanej skręcaniu wyznaczono następujące naprężenia wg [5]:

- normalne:

$$
\sigma_{t o t, E d} \leq \frac{f_{y a}}{\gamma_{M 0}}
$$

- styczne:

$$
\tau_{t o t, E d} \leq \frac{f_{y a} / \sqrt{3}}{\gamma_{M 0}}
$$


oraz naprężenia sumaryczne:

$$
\sqrt{\sigma_{t o t, E d^{2}}+\tau_{t o t, E d}{ }^{2}} \leq 1,1 \cdot \frac{f_{y a}}{\gamma_{M 0}}
$$

$f_{y a}$ - uśredniona granica plastyczności.

Sumaryczne naprężenia normalne i styczne wyznaczono wg [5] ze wzorów:

$$
\begin{gathered}
\sigma_{t o t, E d}=\sigma_{N, E d}+\sigma_{M y, E d}+\sigma_{M z, E d}+\sigma_{w, E d} \\
\tau_{t o t, E d}=\tau_{V y, E d}+\tau_{V z, E d}+\tau_{t, E d}+\tau_{\omega, E d}
\end{gathered}
$$

w których:

$\sigma_{M y, E d}$ - obliczeniowe naprężenia normalne od momentu $\mathrm{M}_{\mathrm{y}, \mathrm{Ed}}$ (w przekroju współpracującym),

$\sigma_{M z, E d}$ - obliczeniowe naprężenia normalne od momentu $\mathrm{M}_{\mathrm{z}, \mathrm{Ed}}$ (w przekroju współpracującym),

$\sigma_{N, E d}$ - obliczeniowe naprężenia normalne od siły podłużnej $\mathrm{N}_{\mathrm{Ed}}$ (w przekroju współpracującym),

$\sigma_{w, E d}$ - obliczeniowe naprężenia normalne od bimomentu (w przekroju brutto),

$\tau_{V y, E d}-$ obliczeniowe naprężenia ścinające od siły poprzecznej $\mathrm{V}_{\mathrm{y}, \mathrm{Ed}}(\mathrm{w}$ przekroju brutto),

$\tau_{V z, E d}$ - obliczeniowe naprężenia ścinające od siły poprzecznej $\mathrm{V}_{\mathrm{z}, \mathrm{Ed}}(\mathrm{w}$ przekroju brutto),

$\tau_{t, E d}$ - obliczeniowe naprężenia ścinające (St. Venanta) od momentu skręcania swobodnego (w przekroju brutto),

$\tau_{\omega, E d}$ - obliczeniowe naprężenia ścinające od momentu skręcania skrepowanego (w przekroju brutto).

Parametry niezbędne do sprawdzenia warunku nośności klapy podano w tabeli 2. Położenie środka ścinania względem środka ciężkości przekroju klapy przedstawiono na rys. 8.

Wartości obliczeniowe oddziaływań przyjęte do obliczeń wynikają z działającego układu obciążenia oraz zastosowania współczynnika konsekwencji zniszczenia $\left(\gamma_{n}=1,1\right)$ zamknięcia wodnego zgodnie $\mathrm{z}[8]$ :

$q_{d y^{\prime}}=45,96 \frac{\mathrm{kN}}{\mathrm{m}}, q_{d z^{\prime}}=30,79 \frac{\mathrm{kN}}{\mathrm{m}}$

Jednostkowy moment skręcający: $m_{s}=42,68 \mathrm{kNm} / \mathrm{mb}$. 
Tabela 2. Parametry geometryczne klapy soczewkowej

Table 2. Geometric data of flap gate

\begin{tabular}{|c|c|c|}
\hline & Oznaczenie & Wartość \\
\hline \multirow{2}{*}{$\begin{array}{c}\text { Momenty bezwładności } \\
{\left[\mathbf{m}^{4}\right]}\end{array}$} & $I_{y 0}$ & $1,11 \cdot 10^{-3}$ \\
\hline & $I_{z 0}$ & $4,51 \cdot 10^{-3}$ \\
\hline \multirow{4}{*}{$\begin{array}{l}\text { Wysokość strefy ściskanej } \\
\text { i rozciąganej [m] }\end{array}$} & $z_{y c}$ & 0,341 \\
\hline & $z_{y t}$ & 0,271 \\
\hline & $z_{z c}$ & 0,760 \\
\hline & $z_{z t}$ & 0,760 \\
\hline \multirow{4}{*}{$\begin{array}{l}\text { Wskaźnik wytrzymałości } \\
{\left[\mathrm{m}^{3}\right]}\end{array}$} & $W_{y c}$ & $3,25 \cdot 10^{-3}$ \\
\hline & $W_{y t}$ & $4,10 \cdot 10^{-3}$ \\
\hline & $W_{z c}$ & $5,94 \cdot 10^{-3}$ \\
\hline & $W_{z t}$ & $5,94 \cdot 10^{-3}$ \\
\hline \multirow{2}{*}{ Moment statyczny $\left[\mathrm{m}^{3}\right]$} & $S_{y}$ & $2,04 \cdot 10^{-3}$ \\
\hline & $S_{z}$ & $4,24 \cdot 10^{-3}$ \\
\hline
\end{tabular}

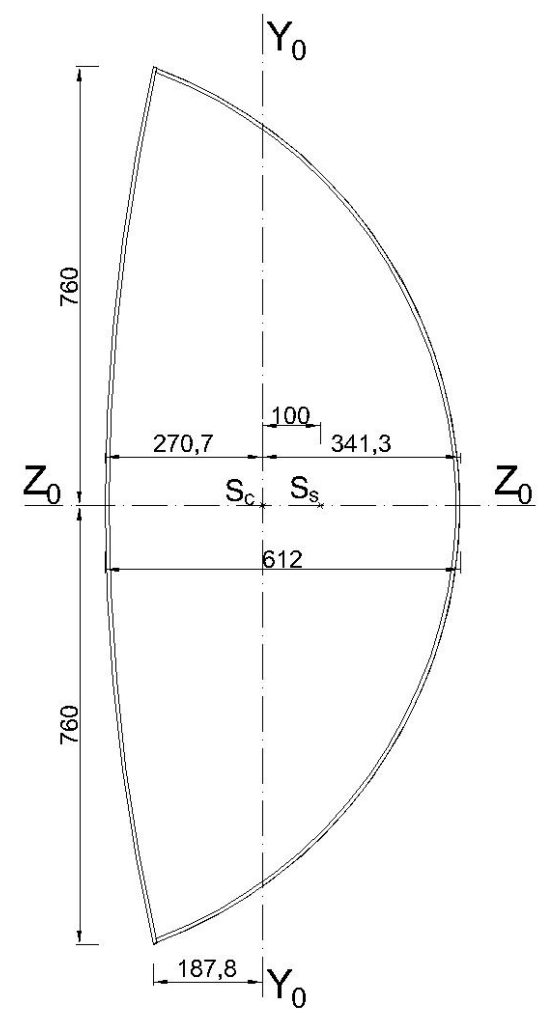

Rys. 8. Położenie środka ciężkości i środka ścinania klapy soczewkowej Fig. 8. Location of centre of gravity and shear centre of flap gate 
$\mathrm{W}$ tabeli 3. przedstawiono wzory, z których wyznaczono naprężenia oraz ich wartości. Naprężenia sprawdzono w środku rozpiętości klapy oraz przy podporze.

Tabela 3. Naprężenia normalne i styczne w przekrojach klapy soczewkowej wg [5]

Table 3. Normal and shear stress in cross-sections of flap gate acc. to [5]

\begin{tabular}{|c|c|c|c|}
\hline Naprężenia [MPa] & Wzór & Przy podporze & $\begin{array}{c}\text { W środku roz- } \\
\text { piętości }\end{array}$ \\
\hline$\sigma_{M y, E d}$ & $\frac{M_{y, E d}}{W_{y}}$ & 0 & 346,46 \\
\hline$\sigma_{M z, E d}$ & $\frac{M_{z, E d}}{W_{z}}$ & 0 & 0,65 \\
\hline$\sigma_{w, E d} *$ & $\frac{\beta_{\omega} \cdot \omega_{(s)}}{I_{\omega}}$ & 0 & 0 \\
\hline$\tau_{V y, E d}$ & $\frac{V_{y, E d} \cdot S_{y}}{I_{y} \cdot t}$ & 98,63 & 0 \\
\hline$\tau_{V z, E d}$ & $\frac{V_{z, E d} \cdot S_{z}}{I_{z} \cdot t}$ & 2,41 & 0 \\
\hline$\tau_{t, E d}$ & $\frac{M_{s}}{2 \cdot F \cdot t}$ & 38,49 & 0 \\
\hline$\tau_{\omega, E d} *$ & $\frac{M_{\omega} \cdot S_{\omega}}{I_{\omega} \cdot t}$ & 0 & 0 \\
\hline$\sigma_{t o t, E d} \leq \frac{f_{y a}}{\gamma_{M 0}}=355$ & j.w. & 0 & $\begin{array}{c}347,2 \\
\text { (wytężenie } 98 \%)\end{array}$ \\
\hline$\tau_{t o t, E d} \leq \frac{f_{y a} / \sqrt{3}}{\gamma_{M 0}}=204,95$ & j.w. & $\begin{array}{c}139,53 \\
(\text { wytężenie } 68 \%)\end{array}$ & 0 \\
\hline$\sqrt{\sigma_{t o t, E d}{ }^{2}+\tau_{t o t, E d}{ }^{2}} \leq 1,1 \cdot \frac{f_{y a}}{\gamma_{M 0}}=390,5$ & j.w. & 139,53 & $\begin{array}{c}347,2 \\
(\text { wytężenie } 89 \%)\end{array}$ \\
\hline
\end{tabular}

*wpływ skręcania skrępowanego w wartości naprężeń normalnych i stycznych na wartości naprężeń sumarycznych jest niewielki (ok. 3\%), więc może zostać pominięty

w których:

$\beta_{\omega}$ - bimoment,

$\omega_{(s)}$ - główne pole wycinkowe,

$I_{\omega}$ - wycinkowy moment bezwładności,

$\mathrm{V}_{\mathrm{y}, \mathrm{Ed}}$ - siła działająca w kierunku poprzecznym do osi y,

$\mathrm{V}_{\mathrm{z}, \mathrm{Ed}}$ - siła działająca w kierunku poprzecznym do osi z,

$F$ - pole ograniczone linią środkową konturu,

$M_{\omega}$ - moment giętno-skrętny,

$S_{\omega}$ - wycinkowy moment statyczny.

Projektowanie klapy soczewkowej jako profilu zamkniętego cienkościennego wiąże się z wyznaczeniem szeregu naprężeń normalnych i stycznych oraz naprężeń sumarycznych wynikających z charakteru i wielkości oddziaływań na 
klapę oraz jej parametrów geometrycznych i wytrzymałościowych. Sprawdzenie stanu granicznego nośności jest pracochłonne, ale pozwala na dokładną weryfikację przyjętych założeń projektowych.

W przypadku sprawdzenia nośności przekroju klapy zgodnie z dotychczasowym podejściem projektowym obliczenia przeprowadza się w ten sam sposób, a wartość naprężeń zastępczych sprawdza się wg wzoru Hubera:

$$
\sigma_{z a s t}=\sqrt{\sigma_{z}^{2}+\sigma_{y}^{2}-\sigma_{z} \cdot \sigma_{y}+3 \tau^{2}} \leq 1,1 f_{d}
$$

Wartości naprężeń (wyznaczonych dla obliczeniowej wartości oddziaływań $\left.q_{\mathrm{dy}}=38,64 \frac{\mathrm{kN}}{\mathrm{m}}\right)$, przedstawiono $\mathrm{w}$ tabeli 4 .

Tabela 4. Naprężenia normalne i styczne w przekrojach klapy soczewkowej zgodnie z (19)

Table 4. Normal and shear stress in cross-sections of flap gate acc. to (19)

\begin{tabular}{|c|c|c|c|}
\hline Naprężenia [MPa] & Wzór & $\begin{array}{c}\text { Przy pod- } \\
\text { porze }\end{array}$ & $\begin{array}{c}\text { W środku roz- } \\
\text { piętości }\end{array}$ \\
\hline$\sigma_{z}$ & $\frac{M_{z}}{W_{z}}$ & 0 & 291,29 \\
\hline$\sigma_{y}$ & $\frac{M_{y}}{W_{y}}$ & 0 & 0 \\
\hline$\sigma_{\omega}{ }^{*}$ & $\frac{\beta_{\omega} \cdot \omega_{(s)}}{I_{\omega}}$ & 0 & 0 \\
\hline$\tau_{y}$ & $\frac{V_{y} \cdot S_{y}}{I_{y} \cdot t}$ & 92,80 & 0 \\
\hline$\tau_{z}$ & $\frac{V_{z} \cdot S_{z}}{I_{z} \cdot t}$ & 0 & 0 \\
\hline$\tau_{s}$ & $\frac{M_{s}}{2 \cdot F \cdot t}$ & 32,59 & 0 \\
\hline$\tau_{\omega}^{*}$ & $\frac{M_{\omega} \cdot S_{\omega}}{I_{\omega} \cdot t}$ & 0 & 291,29 \\
\hline$\sigma_{z a s t} \leq 1,1 \frac{f_{y}}{\gamma_{s}}=339,6$ & $\mathrm{j} \cdot \mathrm{w} \cdot$ & 125,39 & (wytężenie $86 \%)$ \\
\hline
\end{tabular}

*wpływ skręcania skrępowanego w wartości naprężeń normalnych i stycznych na wartości naprężeń sumarycznych jest niewielki (ok. 3\%), więc może zostać pominięty

Analizując uzyskane wyniki przy weryfikacji naprężeń w klapie soczewkowej można zaobserwować, że wyniki obliczeń wykonanych zgodnie dotychczasowym podejściem oraz z zasadami przedstawionymi w Eurokodach są zbliżone. W normie PN-EN 1993-1-3 [5] znajdują się zapisy dotyczące projektowania elementów powłokowych, podczas gdy w normie [2] są odwołania do zasad projektowania prętów cienkościennych o przekroju zamkniętym zawartych w literaturze. Norma [5] przewiduje sprawdzenie wielkości naprężeń normal- 
nych, stycznych oraz sumarycznych i porównanie ich do wartości granicznej określonej dla każdego warunku oddzielnie. Wartość ta zależy od granicy plastyczności stali, z której ma być wykonane zamknięcie oraz współczynnika częściowego do sprawdzenia warunku nośności przekroju poprzecznego $\gamma_{M o} \mathrm{O}$ wartości równej 1,0. Projektując pręt cienkościenny o przekroju zamkniętym zgodnie $\mathrm{z}$ dotychczasowym podejściem sprawdza się wielkość naprężeń stycznych wywołanych skręcaniem, normalnych wywołanych zginaniem, normalnych wywołanych bezpośrednim parciem wody (pkt. 3.1) oraz zastępczych (wzór Hubera) i odnosi do wartości wytrzymałości obliczeniowej.

Porównanie wartości naprężeń sumarycznych lub zastępczych do granicy plastyczności lub wytrzymałości obliczeniowej o wartości powiększonej o $10 \%$ wydaje się ryzykowne w przypadku konstrukcji hydrotechnicznych, na które w najbardziej niekorzystnym układzie działają jednocześnie wszystkie obciążenia o maksymalnej wartości, a wystąpienie awarii może doprowadzić do strat materialnych oraz utraty życia ludzkiego. Skala strat (m.in. zalana powierzchnia terenu) jest uzależniona od klasy budowli i klasy zamknięcia głównego.

Norma [2] zawiera zalecenia dotyczące minimalnych grubości blach i wielkości przekrojów walcowanych jako elementów nośnych zamknięcia wodnego pozwalających na zachowanie zapasu nośności, także ze względu na konieczność manewrowania zamknięciem w trakcie przepływu wody. Tego typu zaleceń, ze względu na zakres jaki obejmują, nie zawierają normy zharmonizowane.

\section{Podsumowanie}

Projektując stalowe zamknięcia hydrotechniczne wg obowiązujących norm zharmonizowanych napotyka się na niejasności i nieuregulowane w normach kwestie z tym związane. Brak jest przepisów, które zawierałyby zasady projektowania zamknięć stalowych, a w szczególności przedstawiałyby sposób przyjęcia i wartości szeregu współczynników częściowych oraz współczynników wartości kombinacyjnej oddziaływań dla budowli i urządzeń hydrotechnicznych, tak jak jest to rozwiązane w przypadku projektowania zbiorników na ciecze. Znajomość sposobu przyjmowania i wartości ww. współczynników jest podstawą do wyznaczenia wartości obliczeniowej efektów oddziaływań na konstrukcję zamknięcia w różnych warunkach jego pracy. Wyznaczenie wielkości obciążeń jest punktem wyjścia do analiz statyczno-wytrzymałościowych, które prowadzi się w procesie projektowania obiektów konstrukcyjnych. Przedstawione w artykule wyniki obliczeń wytrzymałościowych dla klapy soczewkowej pozwalają sformułować wniosek, że można zaprojektować stalowe zamknięcie wodne zgodnie z zasadami podanymi w Eurokodach, jednak jest to proces pracochłonny, a największą trudność stanowi ustalenie wielkości efektów oddziaływań. Ze względu na specyfikę konstrukcji zamknięć wodnych i warunków ich pracy niezbędne jest opracowanie przepisów regulujących zasady jakie należy zachować podczas ich projektowania. 


\title{
Literatura
}

[1] PN-B-03200:1990 Konstrukcje stalowe. Obliczenia statyczne i projektowanie.

[2] PN-B-03203: 2000. Konstrukcje stalowe. Zamknięcia hydrotechniczne. Projektowanie i wykonanie.

[3] PN-EN 1990:2004 Podstawy projektowania konstrukcji

[4] PN-EN 1993-1-1:2006 Projektowanie konstrukcji stalowych. Część 1-1. Reguły ogólne i reguły dla budynków.

[5] PN-EN 1993-1-3:2008 Projektowanie konstrukcji stalowych. Część 1-3. Reguły ogólne - Reguły uzupełniające dla konstrukcji z kształtowników i blach profilowanych na zimno.

[6] PN-EN 1993-1-7: Projektowanie konstrukcji stalowych. Część 1-7. Konstrukcje płytowe

[7] PN-EN 1993-4-2:2007. Projektowanie konstrukcji stalowych. Część 4-2: Zbiorniki.

[8] Rozporządzenie Ministra Środowiska z dn. 20 kwietnia 2007 r. w sprawie warunków technicznych, jakim powinny odpowiadać budowle hydrotechniczne i ich usytuowanie.

\section{DESIGN OF HYDRAULIC GATE (FLAP GATE) ACCORDING TO EUROPEAN STANDARDS}

\begin{abstract}
S u m m a r y
The article presents the results of calculations concerning actions on hydraulic gate: flap gate installed on a segment and resistance of flap gate designed as thin-walled cross-section. The calculations were conducted accordingly to valid standards PN-EN 1990, PN-EN 1993-1-1, PN-EN 1993-1-3, PN-EN 1993-1-7 and PN-EN 1993-4 and to standard which was withdrawn - PN-B03200 and PN-B-03203. The values of actions were calculated for six possible flap gate positions. The analysis of obtained results indicates that the values of impacts calculated acc. to European standards for common operational conditions are overestimated and values calculated for accidental design conditions are significantly underestimated. It indicates the necessity of implementing the regulations concerning the values of partial factors used in design process of hydraulic gates, because the factors implemented in Eurocodes do not reflect the character of actions on hydraulic structures. Furthermore in the article the calculations concerning mechanical resistance of elements of flap gate are presented. Analysis of obtained results reveals that a hydraulic gate such as flap gate may be designed using rules presented in Eurocodes, and the difficulty is in establishing the design values of actions' effects. Due to specificity and operating conditions of hydraulic gates it is necessary to elaborate the document concerning the rules which must be fulfilled in design process.
\end{abstract}

Keywords: hydraulic gate, actions, flap gate, water pressure

Przestano do redakcji: 06.06 .2017 r.

Przyjęto do druku: 01.09.2017 r. 